\title{
ANALISIS KELINCAHAN, KECEPATAN, DAN KOORDINASI MATA-KAKI DENGAN KEMAMPUAN DRIBBLING TIM SEPAK BOLA USS (UIR SOCCER SCHOOL)
}

\section{THE EFFECT OF AGILITY, SPEED, AND EYE-FOOT COORDINATION ON DRIBBLING ABILITY USS (UIR SOCCER SCHOOL) SOCCER TEAM}

\section{Oca Fernandes AF1, Siti Maesaroh ${ }^{2}$, Muhammad Imam Rahmatullah ${ }^{3 *}$, Endang Murti Sulistyowati ${ }^{4}$, Febri Sulistya ${ }^{5}$}

\author{
1,2 Program studi Pendidikan Kepelatihan Olahrga/Fakultas Keguruan dan Ilmu Pendidikan, \\ Universitas Riau, Indonesia \\ ${ }^{3}$ Muhammad Imam Rahmatullah (Program studi Pendidikan Jasmani Kesehatan dan \\ Rekreasi/Fakultas Keguruan dan Ilmu Pendidikan, Universitas Riau, Indonesia \\ ${ }^{4}$ Program Pascasarjana, Universtas Negeri Yogyakarta, Indonesia \\ 5 Program studi Ilmu Keolahragaan/Fakultas Keguruan dan Ilmu Pendidikan, Universitas Mercu \\ Buana), Indonesia
}

\section{*Corresponding Author: Muhammad Imam Rahmatullah, muhammadimamrahmatullah@gmail.com}

Received: 2021-05-23; Revised: 2021-07-13; Accepted: 2021-07-13

\begin{abstract}
Abstrak
Kemampuan dribbling masih menjadi sebuah permasalahan yang dihadapi oleh pemain UIR Soccer School. Melalui hasil pengamatan, seringkali pemain kehilangan kontrol bola saat melakukan perubahan arah dribbling dan melewati lawan. Selain dribbling, permasalahan dalam penelitian ini terlihat dari kurangnya kelincahan dan koordinasi mata-kaki atlet tim sepak bola UIR Soccer School. Hal tersebut mengakibatkan tim kehilangan penguasaan bola dan mengalami transisi negatif dalam permainan. Penelitian ini menggunakan metode kuantitatif dan menggunakan pendekatan korelasional. Tujuan dari penelitian ini untuk membuktikan adanya hubungan kecepatan, kelincahan, koordinasi mata-kaki dengan kemampuan dribbling sepak bola. Populasi penelitian ini adalah pemain UIR Soccer School dengan sampel 30 atlet. Data dikumpulkan mengunakan tes dodging run (mengukur kelincahan), tes lari 30 meter (mengukur kecepatan), modified soccer volley test (mengukur koordinasi mata-kaki) dan tes menggiring bola (mengukur kemampuan dribbling). Hasil analisis dari penelitian ini adalah dibutuhkan latihan yang lebih bervariasi dan kontinyu dalam meningkatkan kecepatan, kelincahan, dan koordinasi mata kaki tim sepak bola UIR Soccer School.
\end{abstract}

Kata Kunci: kecepatan, kelincahan, koordinasi mata-kaki, menggiring bola

\begin{abstract}
Dribbling ability is still a problem faced by UIR Soccer School (USS) players. Through observations, players often lose control of the ball when changing the direction of dribbling and passing opponents. In addition to dribbling, the problem in this study can be seen from the lack of agility and eye-foot coordination of the USS UIR Soccer School soccer team athletes. This resulted in the team losing possession of the ball and experiencing a negative transition in the game. This study uses quantitative methods and uses a correlational approach. This study aims to prove the relationship between speed, agility, eye-foot coordination with soccer dribbling ability. The population of this study was USS players with a sample of 30 athletes. Data were collected using a dodging run test (measures agility), a 30-meter run test (measuring speed), modified soccer volley test (measuring eye-foot coordination) and a dribbling test (measuring dribbling ability). The results are more varied and continuous training is needed to improve the speed, agility, and eye-foot coordination of the UIR Soccer School (USS) soccer team.
\end{abstract}

Keywords: speed, agility, eye-foot coordination, dribbling 
How To Cite: AF, O.F., Maesaroh, S., Rahmatullah, M.I., Sulistyowati, E.M., Sulistya, F. (2021). Analisis kelincahan, kecepatan, dan koordinasi mata-kaki dengan kemampuan dribbling tim sepak bola uss (uir soccer school). Journal of Sport Education (JOPE), 3 (2), 137-145. doi:http://dx.doi.org/10.31258/jope.3.2.137-145

Journal of Sport Education (JOPE) is an open access article under the CC-BY-SA 4.0

\section{PENDAHULUAN}

Sepakbola merupakan olahraga yang cukup popular di Indonesia. Sepakbola adalah olahraga beregu yang dalam permainannya bertujuan untuk mencetak gold dan mendapatkan kemenangan (Fortes et al., 2020). Olahraga sepak bola ini digemari di berbagai kalangan (Mappaompo \& Silatulrahmi, 2015). Sepak bola dalam permainannya dapat dimainkan tanpa mengenal batasan usia (Effendi, 2016). Pada permainan sepak bola, tujuan dari permainan ini bisa untuk sekadar rekreasi atau untuk prestasi (Adityatama, 2017). Globalisasi secara tidak langsung memberikan perbedaan dan persamaan dalam sepak bola dunia (Storm \& Solberg, 2018). Sepak bola pada intinya merupakan olahraga global (Griffin, 2019). Pertandingan olahraga dimanapun berada selalu menarik minat publik untuk menontonnya (Wunderlich \& Memmert, 2018). Sepak bola menjadi daya tarik bagi seluruh masyarakat yang menyukai olahraga beregu ini. Kompetisi sepak bola baik di tingkat nasional maupun international selalu menjadi tontonan yang selalu ditunggu oleh penikmat sepak bola.

Saat ini sepak bola menjadi life style dalam komunitas masyarakat di Indonesia. Di beberapa daerah dan instansi menjadikan sepak bola sebagai ajang untuk mempererat persaudaraan dan menumbuhkan jiwa sportivitas. Di tingkat sekolah, baik itu di jengang sekolah dasar, sekolah menengah pertama, dan sekolah menengah atas, sepak bola menjadi kegiatan ekstrakurikuler yang banyak digemari oleh peserta didik. Hal ini menunjukkan bahwa sepak bola bisa dimainkan oleh seluruh kalangan. Di dalam olahraga seseorang dapat melatih fisik dan mental (Irfan, 2020). Untuk mencapai tujuan dari olahraga sepak bola, diperlukan penguasaan teknik yang baik dari seorang atlet (Adityatama, 2017). Penguasaan teknik dasar yang baik dalam sepak bola akan memudahkan seorang atlet dalam menjalankan taktik dan strategi, hal ini akan membuat kepercayaan diri atlet meningkat dalam bermain (Syafi'i \& Setiawan, 2019). Selain itu, kondisi fisik yang baik juga diperlukan dalam penguasaan teknik (Priya Pratama, Sugiyanto, \& Kristiyanto, 2018). Jika melihat kondisi saat ini, kegemaran terhadap sepak bola di Indonesia bisa dilihat dari semakin banyaknya sekolah sepak bola yang berada di tiap daerah. Kondisi ini memberikan peluang baru bagi pelatih untuk mencari bibit atlet.

Kehadiran sekolah sepak bola ini menjadi harapan bagi Indonesia untuk meningkatkan prestasi di cabang olahraga sepak bola. Selain itu, dengan hadirnya sekolah sepak bola ini merupakan suatu wadah bagi peserta didik yang masih ditingkat sekolah untuk menyalurkan bakatnya di bidang sepak bola. Tentunya, perlu didikan seorang pelatih yang mempunyai kompetensi yang baik untuk menjadikan bibit atlet ini meraih prestasi. Selain itu motivasi internal juga diharapkan untuk meningkatkan kompetensi dan pengetahuan pemain (Hong, Jeong, \& Downward, 2019). Diharapkan dengan kehadiran sekolah sepak bola ini generasi penerus di bidang sepak bola terus bermunculan. Karena dalam bermain sepak bola memerukan keahlihan dan kemampuan teknik dasar (Naldi \& Irawan, 2020).

Persoalan dalam penelitian ini adalah peneliti melihat beberapa atlet masih memiliki kelemahan dalam teknik dasar. Menurut Atiq \& Selamet Budiyanto (2020) Kelemahan teknik dasar dalam bermain sepak bola diantaranya adalah program latihan yang belum terprogram dengan baik. Dalam suatu program latihan, terdapat kemampuan teknis yang harus selalu dilatih, yaitu kemampuan menggiring bola atau dribbling. Dribbbling merupakan kemampuan teknis dalam sepak bola yang mana pemain melakukan suatu pergerakan lari dan melakukan dorongan pada bola (Ardianda \& Arwandi, 2018)

Kemampuan dribbling merupakan kemampuan teknis yang wajib dikuasai oleh atlet 
sepak bola. Kemampuan dribbling merupakan kemampuan seorang pemain dalam mengendalikan bola (Asep Sudharto, Ramdan Pelana, \& Johansyah Lubis, 2020). Dribbling merupakan suatu teknik menggiring bola untuk membuka area lawan untuk menciptakan gol (Andres Budiman, 2019). Kecepatan merupakan suatu gerakan yang seimbang dan dilakukan dalam waktu yang singkat (Sujarwadi \& Sarjiyanto, 20010). Kelincahan adalah perubahan pada posisi tubuh secara cepat (Widiastuti, 2017). Kelincahan merupakan kemampuan teknis yang sangat dibutuhkan dalam permainan sepak bola (Basrizal, Sin, Irawan, \& Soniawan, 2020).

Penelitian ini dilaksanakan karna melihat penurunan performa tim. Untuk itu peneliti ingin menganalisis kecepatan, kelincahan dan koordinasi mata kaki atlet tim sepak bola UIR Soccer School. Selain itu Hal ini dikarenakan, seorang pemain sepakbola jika memiliki kelincahan dan kecepatan dalam performa yang baik akan memudahkannya dalam bermain sepak bola (Akhmad, Zainuddin, \& Bausad, 2018). Koordinasi mata-kaki merupakan kemampuan dari tubuh dalam menyatukan dua atau lebih banyak pola gerak untuk mencapai suatu tujuan (Foran, 2001). Koordinasi mata-kaki menyertakan deretan berbagai kegiatan yang cukup kompleks. Lebih jelasnya, gerakan koordinasi mata-kaki merupakan sebuah reaksi terhadap stimulus, belajar keterampilan dari pengolahan program yang tepat dan tujuan akhirnya yaitu melakukan suatu tindakan yang tepat. Dari penjelasan tersebut dapat dikatakan bahwa koordinasi mata-kaki merupakan sebuah kemampuan teknis yang pada gerakannya menggabungkan dua atau lebih pola gerak untuk mencapai suatu tujuan.

Gerak koordinasi mata-kaki pada pelaksanannya merupakan gerakan yang rumit, sementara pada suatu gerakan yang membutuhkan gerakan yang rumit dibutuhkan proses stimulus yang masuk sehingga diproses menjadi suatu keterampilan gerak yang baik. Koordinasi dalam permainan sepak bola sangat besar perannnya. Koordinasi mata-kaki merupakan keserasian gerakan kaki dan mata secara cepat dan benar (Sakti, 2017). Berdasarkan pengamatan peneliti dan pendapat diatas dapat disimpukan bahwasanya diperlukan penelitian secara kontinyu untuk melihat lebih jauh kecepatan, kelincahan serta koordinasi mata kaki pemain sepak bola UIR Soccer School.

\section{METODE}

Penelitian ini menggunakan metode kuantitatif dengan pendekatan korelasi. Tujuan dari penelitian ini untuk menganalisis kecepatan, kelincahan, koordinasi mata-kaki dengan kemampuan dribbling bola pada permainan sepakbola. Penelitian ini menggunakan analisis data regresi sederhana dan regresi ganda. Pada penelitian ini dalam menguji signifikasi koefisien jalur dengan menggunakan uji $\mathrm{t}$ atau uji $\mathrm{F}$, sedangkan untuk menyatakan signifikan atau tidaknya koefisien jalur didasarkan pada hasil uji t, Uji normalitas dilakukan dengan galat taksiran. Variabel yang dalam penelitian ini yaitu X1 (Kelincahan), X2 (Kecepatan), X1 dan X2 merupakan variabel bebas, dan X3 (Koordinasi) merupakan variabel intervening. Variabel terikatnya yaitu Y (Kemampuan dribbling permainan sepakbola pada Tim UIR Soccer School. Populasi penelitian ini adalah pemain USS dengan sampel 30 atlet. Tempat penelitian di Stadion sepakbola UIR Soccer School. Instrumen untuk mengukur kelincahan menggunakan tes Dodging Run (Ismayarti, 2006). Sedangkan untuk mengukur kecepatan digunakan instrumen teslari 30 meter (Arsil, 2009). Sedangkan untuk mengukur koordinasi digunakan tes koordinasi mata-kaki dalam depakbola (soccer volley test-modifikasi). Untuk mengukur kemampuan dribbling penelitian ini menggunakan tes menggiring bola (Nurhasan, 2001).

\section{HASIL}

\section{Analisis Pengaruh Langsung Kelincahan dengan Kemampuan Dribbling}

Hasil penelitian yang didapatkan dari hasil kali koefisien jalur pyx1 $=0,359$ dengan thitung $=2,867$ dan ttabel(1-0,05)(39-1) =1,70 (pada $\alpha=0,05)$. Karena thitung = 2,867 > ttabel= 1,70, maka Ho ditolak, bearti koefisien jalur signifikan. Dengan demikian kelincahan 
(X1) berpengaruh secara langsung dan signifikan terhadap kemampuan dribbling permainan sepakbola UIR Soccer School (Y). besar pengaruh yang diberikan adalah 13,26\%. Dari hasil berikut dapat disimpulkan bahwa tetap diperlukan latihan kelincahan untuk meningkatkan performa atlit. Latihan yang dapat digunakan adalah S-A-Q (Speed, Agility, Quickness).

Untuk meningkatkan kelincahan pemain dibutuhkan suatu bentuk latihan yang lebih bervariasi (Cania \& Alnedral, 2019). Latihan ini menurut S-A-Q dapat meningkatkan performa kelincahan atlet (Johnson.P \& Bujjibabu, 2021).

\section{Analisis Pengaruh Langsung Kecepatan dengan Kemampuan Dribbling}

Hasil penelitian yang didapatkan dari hasil kali koefisien jalur jalur pyx $2=0,307$ dengan thitung $=2,191$ dan $\mathrm{t}$ tabel $(1-0,05)(39-1)=1,70 \quad($ pada $\alpha=0,05)$. Karena thitung $=2,191>$ ttabel $=1,70$, maka Ho ditolak, bearti koefisien jalur signifikan. Dengan demikian kecepatan (X2) berpengaruh secara langsung dan signifikan terhadap kemampuan dribbling permainan sepakbola UIR Soccer School (Y). Besar pengaruh yang diberikan adalah 8,73\%, maka dapat dipahami bahwa hipotesis yang diajukan sebelumnya diterima kebenarannya. Dari hasil berikut dapat disimpulkan bahwa tetap diperlukan metode latihan kecepatan yang baik untuk meningkatkan performa atlet. Latihan kecepatan yang akan dilakukan untuk meningkatkan performa atlet yaitu latihan speed $A B C$ run.

\section{Analisis Pengaruh Langsung Koordinasi Mata-Kaki dengan Kemampuan Dribbling}

Hasil penelitian yang didapatkan dari hasil kali koefisien jalur jalur pyx3 $=-0,335$ dengan thitung $=-2,392$ dan ttabel $(1-0,05)(39-1)=1,70 \quad($ pada $\alpha=0,05)$. Karena thitung $=-$ $2,392<\mathrm{t}$ tabel $=1,70$, maka Ho ditolak, bearti koefisien jalur signifikan. Dengan demikian koordinasi mata-kaki (X2) berpengaruh secara langsung dan signifikan terhadap Kemampuan Dribbling permainan sepakbola UIR Soccer School (Y). Besar pengaruh yang diberikan adalah 11,97\%, maka dapat dipahami bahwa masih diperlukan latihan untuk meningkatkan koordinasi mata-kaki pada kemampuan dribbling atlet.

\section{Analisis Pengaruh Tidak Langsung Kelincahan Terhadap Kemampuan Dribbling Sepakbola Melalui Koordinasi Pada Tim UIR Soccer School}

Hasil penelitian yang didapatkan pada jalur pada sub struktural 2, diperoleh persamaan $\left(\mathrm{X}_{1}=\mathrm{X}_{3}=\mathrm{Y}\right)$. Nilai koefisien jalur pyx $_{3}=-0,335$ dengan thitung $=-2,392$, рух $_{31}=-0,333$ dengan $t_{\text {hitung }}=-2,090$ dan $t_{\text {tabel }(1-0,05)(39-1)}=1,70$ (pada $\left.\alpha=0,05\right)$. Karena thitung $=-2,392$ dan $-2,090<$ $t_{\text {tabel }}=1,70$ dengan signifikan 0,024 dan 0,046 $<0,05$, maka $H_{o}$ ditolak, bearti koefisien jalur signifikan. Dengan demikian Kelincahan $\left(\mathrm{X}_{1}\right)$ berpengaruh secara tidak langsung dan signifikan terhadap kemampuan dribbling permainan sepakbola UIR Soccer School (Y) melalui koordinasi mata-kaki $\left(\mathrm{X}_{3}\right)$. Besar pengaruh yang diberikan adalah 23,68\%.

\section{Analisis Pengaruh Tidak Langsung Kecepatan Terhadap Kemampuan Dribbling Permainan Sepakbola Melalui Koordinasi Pada Tim UIR Soccer School}

Hasil penelitian yang didaptkan dari hasil perhitungan jalur pada sub struktural 2, diperoleh persamaan $(\mathrm{X} 2=\mathrm{X} 3=\mathrm{Y})$. Nilai koefisien jalur pyx3 $=-0,335$ dengan thitung $=-$ 2,392 , pyx32 $=-0,557$ dengan thitung $=-3,495$ dan ttabel $(1-0,05)(39-1)=1,70 \quad($ pada $\alpha=$ 0,05 ). Karena thitung $=-2,392$ dan $-3,495<$ ttabel $=1,70$ dengan signifikan 0,024 dan $0,002<$ $\alpha=0,05$, maka Ho ditolak, bearti koefisien jalur signifikan. Dengan demikian kecepatan (X2) berpengaruh secara tidak langsung dan signifikan terhadap kemampuan dribbling permainan sepakbola UIR Soccer School (Y) melalui koordinasi mata-kaki (X3), besar pengaruh yang diberikan adalah $25,60 \%$. 


\section{Pengaruh Secara Simultan Kelincahan, Kecepatan dan Koordinasi Terhadap Kemampuan Dribbling Permainan Sepakbola Pada Tim UIR Soccer School}

Hasil penelitian yang didaptkan dari hasil perhitungan Uji individual yang dilakukan $\mathrm{X}_{1}$ $\mathrm{X}_{2}$ dan $\mathrm{X}_{3}$ terhadap $\mathrm{Y}$ didapatkan dari hasil kali Nilai koefisien jalurpyx $x_{21}=0,748$ dengant $_{\text {hitung }}=$ 5,969 dan рух $_{32}=-0,557$ dengant $t_{\text {hitung }}=-3,495$ danpyх $3=-0,335$ dengant $_{\text {hitung }}=-2,392$, dibandingkandengant tabel(1-0,05)(39-1) $=1,70($ pada $\alpha=0,05)$. Karenat ${ }_{\text {hitung }}=5,969,-3,495$ dan $2,392>$ dan $<t_{\text {tabel }}=1,70$ dengan taraf signifikan $0,024,0,002$ dan $0,00<\alpha=0,05$, maka $\mathrm{H}_{\mathrm{o}}$ ditolak, bearti koefisien jalur signifikan. Dengan demikian kelincahan $\left(\mathrm{X}_{1}\right)$, Kecepatan $\left(\mathrm{X}_{2}\right)$ dan Koordinasi mata-kaki $\left(\mathrm{X}_{3}\right)$.) berpengaruh secara simultan dan signifikan terhadap terhadap kemampuan dribbling permainan sepakbola UIR Soccer School (Y), besar pengaruh secara simultan yang diberikan adalah sebesar $71,57 \%$.

\section{PEMBAHASAN}

Berdasarkan hasil analisis dari penelitian ini, faktor kelincahan mempunyai pengaruh secara langsung dan tidak langsung terhadap kemampuan dribbling seorang atlet. Hal ini menunjukkan bahwa faktor kelincahan berperan penting dalam peningkatan performa atlet. Sebagaimana hasil dari penelitian terdahulu yang berjudul "Pengaruh Latihan Kelincahan terhadap Kemampuan Menggiring Bola" berkesimpulan bahwa latihan kelincahan berperan sangat penting dalam meningkatkan performa atlet (Daryanto \& Hidayat, 2015). Selanjutnya, Analisis kecepatan terhadap kemampuan dribbling mempunyai peranan penting dalam meningkatkan performa atlet di lapangan. Kecepatan adalah kemampuan yang dimiliki seorang atlet yang gerakannya dinamis atau berpindah tempat dari titik satu ke titik yang berbeda dalam tempo waktu yang singkat (Hendri Irawadi, 2014). Kemampuan menggiring bola dengan efisien yang dilakukan pemain dapat mengantisipasi pergerakan yang dilakukan secara pasti oleh lawan, karena banyak kemungkinan gerakan yang akan terjadi yang harus diantisipasi sebelumnya.

Faktor kecepatan dalam hal ini diperlukan untuk mengejar dan merebut bola dari lawan ataupun menerima bola dari teman sebagai upaya dalam melakukan serangan kepada lawan. Narasi ini didukung oleh penelitian sebelumnya yang berjudul "Hubungan Antara Kecepatan Lari Dengan Kemampuan Menggiring Bola Sepak Pada Siswa Usia 13-14 Tahun SSB UNIBRAW 82, hasil penelitian tersebut adalah prestasi atlet salah satunya ditentukan oleh faktor kecepatan dan selebihnya ditentukan oleh kondisi fisik atlet (Kurniawan, Nurrochmah, \& H Paulina, 2016). Hasil penelitian ini juga diperkuat oleh penelitian terdahulu yang berjudul "Dribbling determinants in sub-elite youth soccer players" yang menyimpulkan bahwa pemain yang mempunyai kemampuan kecepatan yang baik, dapat melakukan pergerakan dengan bola secara lebih efisien (Zago et al., 2016). Berdasarkan analisis dari penelitian ini, menunjukkan bahwa ada pengaruh kecepatan secara langsung dan tidak langsung terhadap kemampuan dribbling permainan sepakbola UIR Soccer School.

Berdasarkan hasil penelitian ini, juga dapat disimpulkan bahwa koordinasi mata-kaki mempunyai pengaruh langsung terhadap performa atlet. Selain itu, ada pengaruh secara simultan kelincahan, kecepatan, dan koordinasi mata-kaki terhadap kemampuan dribbling. Ketiga teknik ini jika dilakukan dengan baik akan mempermudah seorang atlet untuk melewati lawan dengan cepat serta menghindari kemungkinan cedera yang diakibatkan serangan lawan ketika merebut bola. Hal ini disebabkan karena adanya koordinasi mata-kaki yang baik antara mata dan kaki, mata sebagai indera yang melihat kearah mana bola akan di arahkan dan apa yang akan menghadang pemain ketika membawa bola sedangkan kaki berfungsi untuk media pengantar ke arah mana bola akan melaju.

Penelitian sebelumnya yang berjudul "Hubungan Koordinasi Mata-Kaki terhadap Keterampilan Menggirng Bola pada Permainan Sepakbola" juga menyimpulkan bahwa untuk 
meningkatkan kemampuan dribbling dapat dilakukan dengan cara latihan koordinasi matakaki secara lebih variatif (Supriadi, 2015). Berdasarkan penelitian terdahulu dan penelitian yang dilakukan oleh peneliti menunjukkan bahwa perlu latihan yang lebih variatif dan berkelanjutan dalam meningkatkan kemampuan kecepatan, kelincahan, dan koordinasi matakaki pada seorang atlet. Namun, dalam penelitian ini peneliti mendapatkan beberapa hambatan ketika melakukan penelitian yaitu, tidak terkontrolnya kondisi kesehatan fisik sampel maupun psikologis atlet dan terbatasnya sarana dan prasarana tempat dilakukannya penelitian. Untuk itu perlu kajian lebih dalam lagi dalam penelitian selanjutnya.

\section{SIMPULAN}

Diperolehnya hasil penelitian bahwa kelincahan berpengaruh secara langsung dan tidak langsung terhadap dribbling permainan sepakbola, maka sangat dibutuhkan latihan kelincahan untuk mempertahankan konsistensi atlet dalam upaya meningkatkan dribbling permainan sepakbola dengan melakukan aktivitas gerak yang dapat meningkatkan kelincahan diantaranya lari zigzag, drill. Selanjutnya, hasil analisis dari penelitian ini menunjukkan bahwa kecepatan berpengaruh secara langsung dan tidak langsung terhadap kemampuan dribbling permainan sepakbola, maka perlu dilakukan upaya dalam peningkatan kecepatan agar semakin meningkatkan performa atlet dengan membuat program latihan yang mengutamakan aktifitas gerak sehingga terciptanya kualitas gerak yang baik bagi pemain UIR Soccer School. Hal ini harus diperhatikan oleh pelatih dan lingkungan di manajemen UIR Soccer School untuk meningkatkan aktivitas gerak. Beberapa cara untuk mencapai tingkat kecepatan yang baik yaitu sprint. Hasil analisis selanjutnya dapat disimpulkan bahwa kelincahan, kecepatan, dan koordinasi mata-kaki berpengaruh secara simultan terhadap dribbling permainan sepakbola, maka perlu adanya upaya untuk terus meningkatkan kemampuan koordinasi mata-kaki secara kontinyu dan sistematis. Jika pemain sepakbola UIR Soccer School memiliki koordinasi mata-kaki yang baik, maka hal ini akan meningkatkan kemampuan dribbling pada saat pertandingan dan memperoleh prestasi disetiap pertandingan yang dilakukan. Mengingat koordinasi mata-kaki sangat lah penting. pelatih harus bisa memicu atau melakukan program latihan yang dapat meningkatkan koordinasi mata-kaki dengan cara melakukan latihan koordinasi mata-kaki secara lebih variatif dengan tujuan untuk lebih meningkatkan koordinasi mata-kaki. Selain itu perlu dukungan dari orang tua dan lingkungan sekitar atlet untuk terus mendukung atlet agar tetap konsisten dan mendapatkan hasil yang maximal.

\section{DAFTAR PUSTAKA}

Adityatama, F. (2017). Hubungan Power Otot Tungkai, Koordinasi Mata Kaki Dan Kekuatan Otot Perut Dengan Ketepatan Menembak Bola. JUARA: Jurnal Olahraga, 2(2), 82. https://doi.org/10.33222/juara.v2i2.37

Akhmad, N., Zainuddin, F., \& Bausad, A. A. (2018). Hubungan antara kecepatan dan kelincahan terhadap keterampilan menggiring bola dalam sepak bola pada klub red bee warrior mataram tahun 2018. Jurnal Ilmu Sosial Dan Pendidikan.

Andres Budiman, T. H. S. (2019). Pengaruh latihan kecepatan dan latihan kelincahan terhadap keterampilan dribbling pemain sepakbola ssb putra wijaya. Jurnal Pendidikan Dan Olahraga, 2(1), 177-181.

Ardianda, E., \& Arwandi, J. (2018). Latihan zig-zag run dan latihan shuttle run berpengaruh terhadap kemampuan dribbling sepakbola. Jurnal Performa Olahraga, 3, 32-41. 
Arsil. (2009). Evaluasi pendidikan jasmani dan olahraga. Malang: Wineka Media.

Asep Sudharto, Ramdan Pelana, \& Johansyah Lubis. (2020). Latihan dribbling dalam permainan sepakbola. Gladi: Jurnal Ilmu Keolahragaan, 11(02), 140-150. https://doi.org/10.21009/gjik.112.06

Atiq, A., \& Selamet Budiyanto, K. (2020). Analisis latihan keterampilan teknik dasar sepak bola untuk atlet pemula. Jurnal Pendidikan Jasmani Dan Olahraga, 4(1), 15-22. Retrieved from https://doi.org/10.31539/jpjo.v4i1.1482

Basrizal, R., Sin, T. H., Irawan, R., \& Soniawan, V. (2020). Latihan kelincahan terhadap peningkatan kemampuan dribbling pemain sepakbola roni. Jurnal Patriot Volume, 2(2018), 769-781.

Cania, \& Alnedral. (2019). Tinjauan kondisi fisik atlet atletik jarak menengah unit kegiatan universitas negeri padang. Jurnal Pendidikan Dan Olahraga, 2(1), 192-197. Retrieved from http://jpdo.ppj.unp.ac.id/index.php/jpdo/article/view/217

Daryanto, Z. P., \& Hidayat, K. (2015). Pengaruh latihan kelincahan terhadap kemampuan menggiring bola. Jurnal Pendidikan Olahraga, 4(12), 201-212. Retrieved from https://journal.ikippgriptk.ac.id/index.php/olahraga/article/view/87/85

Effendi, A. R. (2016). Pengaruh latihan koordinasi mata kaki terhadap kemampuan ketepatan shooting pada mahasiswa ukm sepak bola putra awang. Jurnal Pendidikan Olahraga, 5(2), 94-101.

Foran, B. (2001). High-Performance Sports Conditioning. Amerika Serikat: Human Kinetics Publisher.

Fortes, L. S., De Lima-Junior, D., Fiorese, L., Nascimento-Júnior, J. R. A., Mortatti, A. L., \& Ferreira, M. E. C. (2020). The effect of smartphones and playing video games on decisionmaking in soccer players: A crossover and randomised study. Journal of Sports Sciences, 38(5), 552-558. https://doi.org/10.1080/02640414.2020.1715181

Griffin, T. R. (2019). National identity, social legacy and Qatar 2022: the cultural ramifications of FIFA's first Arab World Cup. Soccer and Society, 20(7-8), 1000-1013. https://doi.org/10.1080/14660970.2019.1680499

Hendri Irawadi. (2014). Kondisi fisik dan pengukurannya. Padang: Fakultas Ilmu Keolahragaan Universitas Negeri Padang.

Hong, E., Jeong, Y., \& Downward, P. (2019). Perceived organizational support, internal motivation, and work-family conflict among soccer referees. Managing Sport and Leisure, 24(1-3), 141-154. https://doi.org/10.1080/23750472.2019.1593049

Irfan, M. (2020). Kemampuan teknik dasar sepakbola. Jurnal Patriot, 2, 720-731. Retrieved from http://patriot.ppj.unp.ac.id/index.php/patriot/article/view/664/347 


\section{Journal of Sport Education (JOPE), 2 (2) 2020 - 144}

Oca Fernandes $\mathrm{AF}^{1}$, Siti Maesaroh ${ }^{2}$, Muhammad Imam Rahmatullah ${ }^{3 *}$, Endang Murti Sulistyowati ${ }^{4}$, Febri Sulistya ${ }^{5}$

Ismayarti. (2006). Tes dan pengukuran olahraga. Surakarta: LPP Sebelas Maret Univesity Press.

Johnson.P, \& Bujjibabu, M. (2021). Effect of plyometric and speed agility and quickness (saq) on speed and agility of male football palyers. Asian Journal of Phisical Education and Computer Science in Sport, 7, 26-30.

Kurniawan, D., Nurrochmah, S., \& H Paulina, F. (2016). Hubungan antara kecepatan lari dengan kemampuan menggiring bola sepak pada siswa usia 13-14 tahun ssb unibraw 82 malang. Pendidikan Jasmani, 26(02), 381-397.

Mappaompo, A., \& Silatulrahmi. (2015). Koordinasi mata kaki, keseimbangan, kelincahan, dan keterampilan menggiring dalam sepak bola. Jurnal Penelitian Pendidikan INSANI, (14), $11-16$.

Naldi, I. Y., \& Irawan, R. (2020). Kontribusi kemampuan motorik terhadap kemampuan teknik dasar pada atlet ssb (sekolah sepakbola) balai baru kota padang. Performa Olahraga, 5(1), 39-47.

Nurhasan. (2001). Tes dan pengukuran dalam pendidikan jasmani; prinsip-prinsip dan penerapannya. Jakarta: Direktorat Jendral Olahraga.

Priya Pratama, A., Sugiyanto, S., \& Kristiyanto, A. (2018). Sumbangan koordinasi mata-kaki, kelincahan, keseimbangan dinamis dan fleksibilitas togok terhadap kemampuan menggiring bola pada permainan sepak bola (studi korelasional pada pemain sepak bola mahasiswa universitas nusantara pgri kediri) the contribution . Jurnal SPORTIF : Jurnal Penelitian Pembelajaran , 4(1). Retrieved from http://ojs.unpkediri.ac.id/index.php/pjkVolume4Nomor1Tahun2018

Sakti, B. P. I. (2017). Hubungan koordinasi mata-kaki dan kelincahan dengan keterampilan menggiring bola dalam permainan sepakbola pada siswa ekstrakurikuler SMA Negeri 2 Lubuklinggau. Biormatika : Jurnal Ilmiah Fakultas Keguruan Dan Ilmu Pendidikan, 3(2), 17. Retrieved from http://www.ejournal.unsub.ac.id/index.php/FKIP/article/view/107

Storm, R. K., \& Solberg, H. A. (2018). European club capitalism and FIFA redistribution models: an analysis of development patterns in globalized football. Sport in Society, 21(11), 1850-1865. https://doi.org/10.1080/17430437.2018.1424136

Sujarwadi, \& Sarjiyanto, D. (20010). Pendidikan jasmani olahraga dan kesehatan. Retrieved from https://jurnal.unimed.ac.id/2012/index.php/jpkm/article/view/4646

Supriadi, A. (2015). Hubungan koordinasi mata-kaki terhadap keterampilan menggiirng bola pada permainan sepakbola. 14(1), 6.

Syafi'i, I., \& Setiawan, A. (2019). Koordinasi mata dan kaki pada long passing sepak bola. Physical Activity Journal, 1(2011), 51-60. https://doi.org/https://doi.org/10.20884/1.paju.2019.1.1.1993

Widiastuti. (2017). Tes dan pengukuran olahraga (2nd ed.). Jakarta: PT. BUmi Timur Jaya. 
Oca Fernandes AF ${ }^{1}$, Siti Maesaroh ${ }^{2}$, Muhammad Imam Rahmatullah ${ }^{3}$, Endang Murti Sulistyowati ${ }^{4}$, Febri Sulistya ${ }^{5}$

Wunderlich, F., \& Memmert, D. (2018). The betting odds rating system: Using soccer forecasts to forecast $\quad$ soccer. PLoS ONE, 1-18. https://doi.org/10.1371/journal.pone.0198668

Zago, M., Piovan, A. G., Annoni, I., Ciprandi, D., Iaia, F. M., \& Sforza, C. (2016). Dribbling determinants in sub-elite youth soccer players. Journal of Sports Sciences, 34(5), 411-419. https://doi.org/10.1080/02640414.2015.1057210 